ECONOMICS

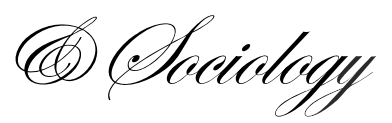

\author{
Jaroslav Belás, \\ Tomas Bata University in Zlin, \\ Zlin, Crech Republic, \\ E-mail: belas111@gmail.com
}

Sergej Vojtovič, Alexander Dubcek University of Trencin,

Trencin, Slovakia, E-mail:sergej.vojtovi@tnuni.sk

\begin{abstract}
Aleksandr Ključnikov, University of Business and Law, Prague, Czech Republic, E-mail: kliuchnikov@gmail.com
\end{abstract}

Received: October, 2015

1st Revision: December, 2015

Accepted: January, 2016

DOI: $10.14254 / 2071-$

789X.2016/9-1/3
Belás, J., Vojtovič, S., Ključnikov, A. (2016), Microenterprises and Significant Risk Factors in Loan Process, Economics and Sociology, Vol. 9, No 1, pp. 43-59. DOI: $10.14254 / 2071-789 X .2016 / 9-1 / 3$

\section{MICROENTERPRISES AND SIGNIFICANT RISK FACTORS IN LOAN PROCESS}

\begin{abstract}
Microenterprises - small companies with their own characteristic features - are a major component of the economic system, which brings positive effects on employment, increases the supply of goods and services, promotes the growth of competition in the market and performs other important functions in the economic system. Microenterprises face sufficient problems with the access to bank financing, which is a base for their sustainable growth. The aim of this paper was to define and quantify significant risk factors of microenterprises' credit financing in the current dynamic economic environment and to compare the significant position of these undertakings in relation to commercial banks by gender, education of the entrepreneur and the company's age. Our research confirmed the impact of the age of the company in the perception of the growing important of the credit risk during the crisis, and the level education of the entrepreneur in relation to the familiarity with the conditions under which the banks provide loans. All other monitored factors do not have any statistically significant impact on the monitored risk factors in the loan process. Our results show that the main problems of the micro enterprises are an absolute unfamiliarity with the credit conditions of the commercial banks across the entire spectrum of the researched groups, and their persuasion of the lending criteria to be non-transparent.
\end{abstract}

JEL Classification: L26, O16, G32
Keywords: microenterprises, external financing, commercial banks, credit risk.

\title{
Introduction
}

Small and medium-sized enterprises (SMEs) make a major contribution to growth and employment in the EU. In today's fierce competition in the market economic activities, the SMEs gradually developed into a major force for national economic and social development (Shuying and Mei, 2014).

Microenterprises represent an important part of the SME segment. Defined as a small, owner-operated enterprise typically started by a member of a marginalized segment of the population, these businesses take on various organizational forms to contend with entry 
barriers and capital constraints (Munoz et al., 2015; De Mel, McKenzie, and Woodruff, 2010; Bruhn, 2013).

Financial risk management has received increased attention over the past years because of financial risks, though they are not a core competency of non-financial firms, they also influence their business operations, financial performance and the future of the company to a large extend. The ability of SMEs to grow highly depends on their potential to invest in restructuring, innovation and qualification. All of these investments need capital and therefore an access to finance (European Association of Craft, SMEs, 2007).

The effect of the access to finance on entrepreneurship and microenterprise growth is of vital importance for poverty reduction and economic growth in developing countries (Beck, Lu, and Yang, 2015).

Entrepreneurs' characteristics, such as gender, level of education, age, managerial skills, and experience, in addition to physical and emotional family support, are the important factors that influence business success (Munoz et al., 2015; Kozubíková et al., 2015a; Bartoš et al., 2015) and represent significant factors which determine the approach to financial risk management and access to external financing through bank loans (Belas et al., 2015; Doležal et al., 2015).

The aim of this paper is to define and quantify significant risk factors of microenterprises' credit financing in the current dynamic economic environment and to compare the significant position of these undertakings in relation to commercial banks by gender, education of the entrepreneur and the company's age. The paper is based on the survey of the quality of the business environment carried out in 2015 in Czech Republic on a sample of 1141 small and medium sized enterprises, 740 of which were reported as microenterprises. Our research has some limitations, specifically the geographical focus only on the Czech Republic. This problem is significant because country's specific macro environment can also affect the possibility to get the loan by the SMEs (Drakos and Giannakopolous, 2011). A wider geographical focus of the further researches may bring more fundamental results.

Theoretical part of this paper introduces the characteristics of a microenterprises, important factors for financing of such type of companies, and the potential influence of the gender and education of the entrepreneur, and the age of the company. The second part of the article presents a detailed description of the research methodology, scientific methods, collected data, and a definition of the alternative working hypotheses. The third chapter of our article presents the results of the research, along with a brief discussion. The final section presents the summary of the essential results of our research.

\section{Theoretical background}

Microenterprises have some characteristic features in comparison with small and medium size enterprises (SMEs). They are typically firms that are smaller than the SMEs, with few employees and often without formal status (Beck, Lu, and Yang, 2015).

According to Fetisovová, Hucová, Nagy and Vlachynský (2012) Small and medium sized enterprises have a number of specifics that are related to their size: a lower degree of diversification, low capital strength, limited markets and higher risk. On the other hand, they are more flexible and have a closer contact with customers.

Concise nature of these enterprises is presented by Larson and Shaw (2001). According to the authors, these companies have the following characteristics: 1. mostly family-owned with family members working in the business, 2. driven by one person, 3. located primarily in rural areas, 4. involved in trading and manufacturing, 5. characterized 
by multiple start-up and failure rates, 6 . founded primarily by women, and 7 . operated on a small basis with low income earnings.

Different authors emphasize different aspects of microenterprises. Beck (2013) highlights: „Subsistence entrepreneurs have tiny businesses, based on self-employment and informality and are almost exclusively micro-entrepreneurs. Many of these enterprises are set up out of a lack of alternative employment options for the owner in the formal sector. They rely almost exclusively on the owner, maybe with support from family members and/or friends. There is evidence that such subsistence entrepreneurs make up the majority of microenterprises".

According to De Mel, McKenzie, and Woodruff (2010) and Bruhn (2013) microentrepreneurs have very close characteristics to the wage workers and it is probable that they won't have big plans for the expansion of their business. This is an interesting fact which can also influence their relation to bank loans.

According to Munoz et al. (2015) microenterprises utilize creative entrepreneurial approaches that are often characterized by chaos.

The management of the microenterprise is a key contributor to business success (Munoz et al., 2015). Key management practices, marketing capability, and technology capability of microenterprises have a positive impact on performance sales, net profit, and growth (Welsh et al., 2013; Mostenska et al., 2015).

Berrone et al. (2014) find that human capital (proxied by educational level and degree of dedication), innovation, and intensity of use of own capital are important determinants of the microenterprise's performance.

The smaller size of the microenterprises escalates the importance of certain business risks for this group of entrepreneurs. Entrepreneurial risk has a complex form since it includes a number of interconnected partial risks. Fetisovová et al. (2012) defines such forms of business risks as strategic risk, operational risk, financial risk, sociopolitical risk and reputation risk.

The risk of insufficient demand (market risk) is currently quite significant. According to Carson (2013), the greatest threats to business of the British SMEs are: weak demand due to economic stagnation (presented by $52 \%$ of entrepreneurs), operational cost challenge $(37 \%)$, inadequate cash reserves $(27 \%)$, poor access to finance $(21 \%)$, and failure to manage cash flow (17\%). The most important business risks perceived by entrepreneurs in the Czech Republic and Slovakia in 2013 were as follows: market, financial and personnel risks. Market risk was identified as a key risk by the largest number of entrepreneurs, which means $79.44 \%$ of the respondents in the Czech Republic and $80.49 \%$ in Slovakia (Belás et al., 2015a, Buganová et al., 2014, Belás et al., 2014).

Loan process and gaining of the external bank financing are interconnected with the financial risk. The views of the different authors on the definition of financial risk differ to some extent. E.g. by Fetisovová et al. (2012) financial risks are related to the financial markets development and the use of single financial instruments. They have a complex nature and can be classified into the following groups: funding risk, credit risk, liquidity risk, the risk of interest rate changes, currency risk, inflation risk and counterparty default risk.

According to Shuying and Mei (2014) financial risk is one of the risks any enterprise can't avoid; therefore, the company managers should easily make financial decisions under the risky and uncertain situation. In the process of development, with various uncertain factors such as natural environment and social economic environment, the risks that SMEs are facing are also gradually increasing. In this case, we must take timely measures to ensure that SMEs are in an invincible position in the market competition (Skapa, 2013; Mentel \& Brożyna, 2015). 
Therefore, correct understanding of financial risk and presentation of operable financial risk warning methods is of great significance. The characteristics of financial risk are objectivity, uncertainty, comprehensive, and duality.

Financial risk refers to the process of daily affairs, due to the interference of some external and internal factors things don't develop with the expected phase deviation, and therefore this circumstance raises the risk that the status of the enterprises finance won't be as normal as it was planned. The lack of access to external financing through bank loans is a very important consequence of the financial risk (Shuying and Mei, 2014; Brauers and Zavadskas, 2011).

The term, interconnecting the financial risk, the knowledge and the transparency of the bank's credit conditions, the presentation of the company's accounting data in the loan obtaining process is the financial gap. This term means a situation when a sizeable share of economically significant SMEs cannot obtain financing from banks, capital markets or other suppliers of finance. OECD (2006), International Finance Corporation (2013), Bain \& Company, Inc. and the Institute of International Finance (2013), Sobeková, Sipko, and Solík (2014), Fetisovová et al. (2012), European Association of Craft, Small and medium-sized Enterprises (2007) similarly state that SMEs are influenced by the financing gap.

The difficulties that SMEs experience can stem from several sources. The domestic financial market may contain an incomplete range of financial products and services. The lack of appropriate financing mechanisms could stem from a variety of reasons, such as regulatory rigidities or gaps in the legal framework. Moreover, development economists increasingly accept the proposition that, due to monitoring difficulties such as principal/agent problems (e.g. related to the shareholder-manager relationship) and asymmetric information (for example Deakins, Whittam, and Wyper, 2010). SMEs' difficulty in obtaining financing will be compounded when the business environment lacks transparency, when the legal system is weak, and when monopolies are present. As well, loan originators may avoid providing financing to certain types of SMEs, in particular, startups and very young firms that typically lack sufficient collateral, or firms whose activities offer the possibilities of high returns, but at a substantial risk of loss. In a competitive market, suppliers of finance have powerful incentives to overcome barriers to SME finance (OECD, 2006).

An important tool to improve an approach of micro-enterprises to external financing through bank loans is a transparent approach of both parties involved (Bain \& Company, Inc. and the Institute of International Finance, 2013; European Association of Craft, Small and medium-sized Enterptises, 2007).

The complexity of the problem with the bank financing of microenterprises became even more evident due to the financial crisis. Crises in the world made banks more careful. According to Holton, Lawless, and McCann (2013) "one of the defining features of the recent Euro Area crisis has been the significant contraction in credit to the real economy, along with the large variation in the pace of this decline across countries". They declare that smaller companies faced tougher credit conditions during the crises and that there were great differences in interest rates across the European Union countries. The authors bring interesting evidence about fact that microenterprises and companies with lower turnover are more likely to be rejected, whereas age and subsidiary status are not significant. And what about the other factors than only only size of the company? Authors at the base of the research inform that: "Firms that have improved or unchanged internal funds, credit history or capital (relative to deteriorated) are less likely to be rejected".

Small firms are facing more financial constraint than medium sized firms (Dong and Men, 2014; Hernández-Cánovas and Koëter-Kant, 2011) due to larger asset base (Yildirim, Akci, and Eksi, 2013) that can be used as collateral while asking for loans (Dong and Men, 2014). High collateral requirement has been identified as one of the major reasons for the 
lower level of credit to SMEs in the Baltic States (Rupeika-Apoga, 2014; Beck, 2013; Armstrong et al., 2013). Drakos and Giannakopolous (2011) found that the companies with more employees have more chances to get loans from the bank than the smaller firms do.

This paper presents the results of our research in relation to the potential influence of the gender and education of the entrepreneur, and the age of the company.

The factor of the gender of the entrepreneur is of a great importance in relation to the credit risk and loan process. Several authors (Deakins, North, Baldock, and Whittam, 2008; Global Markets Institute, 2014) state that SMEs owned and managed by women were more credit constrained than the men owned companies. According to North, Baldock, and Ekanem (2010) the reason is that women entrepreneurs suppose the refusal of their credit application, so they do not even apply for the loan.

According to Drakos and Giannakopolous (2011) a male owned enterprises are less credit rationed than the females owned enterprises because women are more risk averse than men and hence they are not willing to take more risk and to take loans.

Carter et al. (2007) examined the effect of gender in the bank lending process to the small business when the loan applicant was a female or male. The authors have differentiated the supply side as well as demand side by the information whether the loan officer is female or male. The paper finds some distinct criteria for loan processing, while the loan applicant is male or female, on the other hand, when the loan officer is male or female. They have found that, when considering an application, applicant education plays an important role; lower level of education for female applicant had mostly led to rejection. However, when considering for the higher level of education, the gender criteria for loan processing diminishes. It is found that, when the loan applicant is male, the loan officer is most likely to know about the business plan, financial history and general characteristics of the applicant. On the other hand, for female applying the loan officers are more interested to know whether she has done enough research and her educational background is mostly discussed.

The discussion about the impact of the level of education of the entrepreneur may shoud include the opinion of Irwin and Scott (2010), whose results indicate that banks are more comfortable to finance the educated entrepreneurs than their colleagues with the secondary education due to advanced knowledge of the business propositions and more organized loan proposals. Rauch and Rijsdijk (2013) state that the higher education of the entrepreneur, including other types of education like vocational training or higher school certificate is positively related to business growth. They have reasoned that, people with higher education can actively seek for new opportunities which are positively related to higher growth.

Quite an opposite opinion was presented in the studies by Kozubíkova et al. (2015b) or Belás et al. (2015b), where no significant differences in approaches of the SME entrepreneurs to financial risk management in relation to gender and level of education were identified.

The last monitored factor was the age of the company. Basic assumption is that the older the company is, the more experience in relations with banks and loan applications it has. North, Baldock, and Ekanem (2010), Deakins, Whittam, and Wyper (2010), Deakins et al. (2008) state that new and early stages SMEs are facing more financing problems from the bank than their more established counterparts. The research by Kozubíková et al. (2015b) showed that the size of the company plays an important role in the evaluation of the financial risk.

The age of the company usually has a causal link to its size. Hernández-Cánovas and Koëter-Kant (2011) confirm the relation between the size of the company and debt maturity. They declare that debt financing contracts for smaller firms are more subject to the institutional environment than for larger firms, because small companies are financially more 
constrained and more dependent on domestic capital markets (mostly bank loans) in time when the outside financing is needed. There is also another problem. McCarthy, Oliver, and Verreynne (2015) say that SMEs are usually less transparent and they present the lack of financial data.

\section{Research Methodology, Objective and Data}

The objective of this paper is to define and quantify significant risk factors of microenterprises' credit financing in the current dynamic economic environment and to compare the significant position of these undertakings in relation to commercial banks by gender and education of the entrepreneur and the company's age in the sector of microenterprises.

The paper is based on the survey of the quality of the business environment carried out in 2015 in Czech Republic on a sample of 1141 small and medium sized enterprises, out of a total number of 1650 randomly selected companies. The questionnaire available at https://docs.google.com/forms/d/1U9coaC5JRL0N2QOOO6Xb8j3mnaZXdSM47Kugt4EDG Fo/viewform?usp=send_form, which consisted of 52 questions, was presented to the companies, selected from Albertina database. 740 out of 1141 respondents belonged to the category of microenterprises according to the EU definition of SMEs is described in the EU recommendation $\# 2003 / 361$, where the main factor determining the category of the enterprise is staff headcount, when microenterprises should employ up to 9 employees. The respondents of the survey represented all 14 regions of the Czech Republic.

The structure of the respondents from the group of microenterprises was as follows: $73 \%$ men, $27 \%$ women; $71 \%$ of respondents reported to have secondary education, $29 \%$ had the university degree; $53 \%$ of companies' owners stated that the company exists for more than 10 years, $47 \%$ of them declared that their companies operate for a less than 10 years. The age of the researched companies was as follows: $62 \%$ were established more than 10 years ago, $21 \%$ operated between 1 and 5 years, and $17 \%$ of them operated between 5 and 10 years. Most of the total number of the respondents reported to have secondary education $(48 \%)$, $34 \%$ of them had a university degree and $18 \%$ declared secondary education without graduation.

Our research used the tools of descriptive statistics, including percentages and averages, pivot tables, the methods of comparison and deduction, Pearson's chi-square statistics at 5\% significance level for the verification of the existence of the statistically significant dependences and differences between the selected factors. The calculation were made in MS Excel and in the statistical software available at www.socscistatistics.com. Statistically significant differences in the individual responses were investigated by the means of Z-score. The calculations were made through the free software available at: http://www.socscistatistics.com/tests/ztest/Default2.aspx

This paper presents only selected results of the research due to the length limitations.

For this paper we set four alternative working hypotheses by the method of expert estimation. The hypotheses were assigned with the abbreviations of $\mathrm{H} 1$ to $\mathrm{H} 4$. The alternative hypotheses were supplemented by the null hypotheses assuming there were no statistically verifiable differences between the researched factors. Null hypotheses: There is no statistically significant dependences between the chosen factors (gender, education of the entrepreneur, age of the company) and the chosen filed of research.

Null hypothesis means that $\pi_{1}=\pi_{2}$, so $\pi_{1}=\pi_{2}=0$, while the alternative hypothesis states that $\pi_{1}=\pi_{2} \neq 0$.

H1: There is a statistically significant difference between the gender and education of the entrepreneur, the age of the company and the opinion that the importance of credit risk 
grew during the crisis. We suppose that at least $60 \%$ of microenterprises agree with this opinion.

$\mathrm{H} 2$ : There is a statistically significant difference between the gender and education of the entrepreneur, the age of the company and the opinion that microenterprises are not well acquainted with the credit conditions. We suppose that more than $30 \%$ of entrepreneurs confirm to have a thorough understanding of the lending conditions of the commercial banks.

H3: There is a statistically significant difference between the gender and education of the entrepreneur, the age of the company and the opinion that the conditions under which banks provide loans to SMEs are not transparent. We suppose that a maximum of $30 \%$ of entrepreneurs agree with the opinion, that credit conditions are transparent.

H4: There is a statistically significant difference between the gender and education of the entrepreneur, the age of the company and the opinion that better knowledge of credit criteria allows the entrepreneurs to have an easier access to credit and to better price conditions. We suppose that this approach will present a minimum of $60 \%$ of entrepreneurs in the segment of microenterprises.

\section{Results and discussion}

The results of the research devoted to the assessment of the intensity of credit risk in the current economic environment of SMEs in the Czech Republic are presented in Table 1.

Table 1. Assessment of the intensity of credit risk in the Czech Republic gender, education and the company's age

\begin{tabular}{|c|c|c|c|c|c|c|c|c|}
\hline $\begin{array}{l}\text { The importance } \\
\text { of credit risk } \\
\text { grew during } \\
\text { the crisis }\end{array}$ & Total & Men & Women & $\begin{array}{l}\text { Secondary } \\
\text { education }\end{array}$ & $\begin{array}{l}\text { Other } \\
\text { types of } \\
\text { education }\end{array}$ & $\begin{array}{l}\text { Older } \\
\text { than } 10 \\
\text { years } \\
(10+)\end{array}$ & $\begin{array}{l}\text { Younger } \\
\text { than } 10 \\
\text { years } \\
(10-)\end{array}$ & $\begin{array}{c}\mathrm{p} \text {-value } \\
\mathrm{Z} \text {-score } \\
\mathrm{M} / \mathrm{W} \\
\mathrm{HE} / \mathrm{OE} \\
10+/ 10-\end{array}$ \\
\hline $\begin{array}{l}\text { 1. Completely } \\
\text { agree }\end{array}$ & 61 & 50 & 11 & 17 & 44 & 41 & 20 & $\begin{array}{l}0.0989 \\
0.8337 \\
\mathbf{0 . 0 1 7 8} \\
\end{array}$ \\
\hline 2. Agree & 397 & 290 & 107 & 105 & 292 & 219 & 178 & $\begin{array}{l}0.9601 \\
0.0930 \\
0.1499 \\
\end{array}$ \\
\hline $\begin{array}{l}\text { Share in \% } \\
(1+2)\end{array}$ & 61.89 & 62.96 & 59.00 & 56.74 & 64.00 & 66.67 & 56.57 & $\begin{array}{l}0.3222 \\
0.0643 \\
\mathbf{0 . 0 0 4 8} \\
\end{array}$ \\
\hline $\begin{array}{l}\text { 3. I don't have } \\
\text { a position }\end{array}$ & 217 & 154 & 63 & 74 & 143 & 100 & 117 & \\
\hline 4. Disagree & 56 & 39 & 17 & 18 & 38 & 25 & 31 & \\
\hline $\begin{array}{l}\text { 5. Completely } \\
\text { disagree }\end{array}$ & 9 & 7 & 2 & 1 & 8 & 5 & 4 & \\
\hline Total: & 740 & 540 & 200 & 215 & 525 & 390 & 350 & \\
\hline $\begin{array}{l}\text { chi-square/ } \\
\text { p-value }\end{array}$ & & $\begin{array}{l}3.3658 \\
0.4986 \\
\end{array}$ & & $\begin{array}{l}5.6961 \\
0.2230 \\
\end{array}$ & & $\begin{array}{c}11.4207 \\
0.0222 \\
\end{array}$ & & \\
\hline
\end{tabular}

Note: The credit risk is perceived as a risk of the loan rejection

Source: own calculation.

The research results confirmed that there is a statistically significant difference in the overall responses of microenterprises disaggregated according to the age of the company. The $p$-value of 0.0222 indicates that the result is significant at $p<0.05$. Older firms presented 
a significantly more favorable opinion ( $\mathrm{p}$-value $=0.0048$ ) in comparison with younger microenterprises. The $p$-value of 0.0048 indicates that the result is significant at $p<0.01$, which is a very solid result. On the other side no statistically significant difference was identified in relation to the gender and education of the entrepreneur, where the $\mathrm{p} / \mathrm{values}$ were correspondingly 0,4986 and 0,2230 . These facts allow us to confirm our working alternative hypothesis $\mathrm{HI}$ in relation to the age of the company, and to reject working alternative hypothesis $\mathrm{H} 1$ in relation to the gender and education of the entrepreneur.

Our assumption that at least $60 \%$ of microenterprises agree with the opinion that the importance of credit risk increased during the crisis was confirmed. The representatives of $61.89 \%$ of the total number of microenterprises agreed with this opinion. More intensive agreement with this statement was presented by older companies (66.67\%). An interesting finding is that younger microenterprises $(56,57 \%)$ and those small companies whose owners have secondary education $(56,74 \%)$, have showed a relatively low intensity of consent with this statement.

Our results present affirmative results with the works of other authors. Ardic, Mylenko, and Saltana (2012) state that the problem of obtaining of the bank loans by the SMEs has further increased during the economic crisis, when SME financing was significantly reduced in the developed countries. Economic \& Social Research Council (2010) states that overdraft loan rejections increased $3 \frac{1}{2}$ times (from $4.2 \%$ to $15.3 \%$ ), term loan rejections increased $2 \frac{1}{2}$ times (from $6.1 \%$ to $16.3 \%$ ), overdraft margins increased by $83 \%$ (from $2.4 \%$ points to $4.4 \%$ points over base), overdraft arrangement fees increased by $86 \%$ (from $£ 237$ to $£ 442$ ), term loan margins increased by $68 \%$ (from $2.2 \%$ to $3.7 \%$ points over base), term loan arrangement fees increased by $37 \%$ (from $£ 1,074$ to $£ 1,468$ ) in the United Kingdom in 2008.

SMEs continued to face the dual challenges of an uneven recovery and bank deleveraging in 2012. The challenging macroeconomic environment, characterized by subdued growth and demand, translated into declining profits for SMEs and reduced availability of internal funding. At the same time, the financial sector continued the deleveraging process started in the aftermath of the crisis, with banks endeavoring to meet Basel III Capital and leverage ratio requirements through a combination of asset reduction and capital rising. In some countries, the sovereign debt crisis increased the deficiencies in capital adequacy. This squeezed credit availability for the entire banking system, but impacted SMEs more than large firms. SMEs and entrepreneurs continued to face greater vulnerability to credit market conditions due to their heavy reliance on bank credit (OECD, 2014).

Credit conditions remained tighter for SMEs in relation to large firms. In 2012, while 18 out of 31 countries experienced declining nominal interest rates, interest rate spreads between small and large enterprises increased in most cases. Moreover, in most Scoreboard countries, collateral requirements also increased during 2012. This reflected heightened risk aversion of the part of banks (OECD, 2014).

The research by Economic \& Social Research Council (2010) confirms that the credit crisis and ensuing recession have led to both a tightening of loan approval thresholds (due to the crisis in financial markets) and an increase in default risk (due to the ensuing recession), contributing to the poorer availability of credit.

Our results could be synthetically interpreted to show a significant growth of the credit risk across the entire spectrum of microenterprises. The results of our research are compatible with findings of Sobeková, Sipko, and Solík (2014), Kalusová (2014), International Finance Corporation (2013), Bain \& Company, Inc. and the Institute of International Finance (2013), Fetisovová et al. (2012). I in this context Závadský, Hitka, and Potkany (2015) state that the economic crisis can also initiate some optimization and organizational restructuring of the enterprises. 
The results of our investigation are not compatible with the findings of North, Baldock, and Ekanem (2010), Deakins, Whittam, and Wyper (2010), Deakins et al. (2008). Our research has neither confirmed the findings by Deakins et al. (2008) and Global Markets Institute (2014) that SMEs owned and managed by women are more credit constrained than the men owned SMEs.

The results of the research of the knowledge of credit conditions by microenterprises in the Czech Republic are presented in Table 2.

Table 2. Assessment of the knowledge of credit conditions by microenterprises

\begin{tabular}{|c|c|c|c|c|c|c|c|c|}
\hline $\begin{array}{l}\text { Entrepreneurs } \\
\text { are thoroughly } \\
\text { familiar with the } \\
\text { conditions under } \\
\text { which the banks } \\
\text { provide loans to } \\
\text { SMEs }\end{array}$ & Total & Men & Women & $\begin{array}{l}\text { Secondary } \\
\text { education }\end{array}$ & $\begin{array}{c}\text { Other } \\
\text { types of } \\
\text { education }\end{array}$ & $\begin{array}{c}\text { Older } \\
\text { than } 10 \\
\text { years } \\
(10+)\end{array}$ & $\begin{array}{c}\text { Younger } \\
\text { than } 10 \\
\text { years } \\
(10-)\end{array}$ & $\begin{array}{c}\mathrm{p} \text {-value } \\
\text { Z-score } \\
\mathrm{M} / \mathrm{W} \\
\mathrm{HE} / \mathrm{OE} \\
10+/ 10-\end{array}$ \\
\hline $\begin{array}{l}\text { 1. Completely } \\
\text { agree }\end{array}$ & 8 & 7 & 1 & 5 & 3 & 4 & 4 & \\
\hline 2. Agree & 179 & 134 & 45 & 33 & 146 & 106 & 73 & \\
\hline Share in $\%(1+2)$ & 25.27 & 26.11 & 23.00 & 17.67 & 28.38 & 28.21 & 22.00 & \\
\hline $\begin{array}{l}\text { 3. I don't have a } \\
\text { position }\end{array}$ & 233 & 168 & 65 & 72 & 161 & 120 & 113 & \\
\hline 4. Disagree & 296 & 216 & 80 & 95 & 201 & 149 & 147 & $\begin{array}{l}1.0000 \\
0.1362 \\
0.2937 \\
\end{array}$ \\
\hline $\begin{array}{l}\text { 5. Completely } \\
\text { disagree }\end{array}$ & 24 & 15 & 9 & 10 & 14 & 11 & 13 & $\begin{array}{l}0.2420 \\
0.1676 \\
0.4902 \\
\end{array}$ \\
\hline Together: $4+5$ & & & & & & & & $\begin{array}{l}0.6745 \\
\mathbf{0 . 0 4 8 8} \\
0.1971 \\
\end{array}$ \\
\hline Total: & 740 & 540 & 200 & 215 & 525 & 390 & 350 & \\
\hline $\begin{array}{l}\text { chi-square/ } \\
\text { p-value }\end{array}$ & & $\begin{array}{l}2.6035 \\
0.6262\end{array}$ & & $\begin{array}{c}17.6980 \\
0.0014\end{array}$ & & $\begin{array}{l}4.3248 \\
0.3638\end{array}$ & & \\
\hline
\end{tabular}

Source: own calculation.

The mail result of this part of the research is the finding, that microenterprises are unfamiliar with the credit conditions of the banks. The research results confirmed that there is a statistically significant difference in the overall responses of microenterprises disaggregated according to the education of the entrepreneur, when university educated business owners in comparison to those with other types of education significantly more presented the researched opinion. The $p$-value of 0.0014 indicates that the result is significant even at $p<0.01$, which is almost a level of certainty. No statistically significant difference was identified in relation to the gender of the entrepreneur and the age of the company, where the $\mathrm{p} / \mathrm{values}$ were correspondingly 0,6226 and 0,3638. These facts allow us to confirm our working alternative hypothesis $\mathrm{H} 2$ in relation to the education of the entrepreneur, and to reject working alternative hypothesis $\mathrm{H} 2$ in relation to the gender of the entrepreneur and the age of the company.

Basic finding, arising from this part of the research is that microenterprises do not thoroughly understand the commercial banks' credit conditions. This trend was demonstrated 
across the entire spectrum of microenterprises. Only $25.27 \%$ of entrepreneurs agreed with the argument that entrepreneurs are thoroughly familiar with loan conditions of commercial banks, so our assumption that more than $30 \%$ of entrepreneurs confirm to have a thorough understanding of the lending conditions of the commercial banks was incorrect. The finding that the entrepreneurs with lower education declared that they know credit conditions of commercial banks better than higher educated counterparts seem to be abnormal. We assume that the psychological effect can be a possible explanation; this means that entrepreneurs who have less knowledge of the credit terms more intensively believe that they understand this subject. The words of Percy Bysshe Shelley sound great in this context: "The more we learn, the more you reveal their ignorance".

Our findings can be supported by the research of Sobeková Majková (2011), who stated that microenterprises are less informed about financial resources than bigger companies. According to the research of this author $61 \%$ of microenterprises wish to obtain more information about bank loans' conditions. It is 5\% less than average from all other size categories of enterprises (66.2\%). According to her study microenterprises mainly wish to obtain more information about financing possibilities from the EU structural funds $(62.6 \%)$, than about the bank credits $(61.1 \%)$ or venture capital (32.8\%).

The results of the research in the area of transparency of the credit conditions in the Czech Republic are presented in Table 3.

Table 3. Assessment of the transparency of credit conditions

\begin{tabular}{|c|c|c|c|c|c|c|c|c|}
\hline $\begin{array}{l}\text { Conditions under } \\
\text { which the banks } \\
\text { provide loans to } \\
\text { SMEs are } \\
\text { transparent }\end{array}$ & Total & Men & Women & $\begin{array}{l}\text { Secondary } \\
\text { education }\end{array}$ & $\begin{array}{l}\text { Other } \\
\text { types of } \\
\text { education }\end{array}$ & $\begin{array}{c}\text { Older } \\
\text { than } 10 \\
\text { years } \\
(10+)\end{array}$ & $\begin{array}{c}\text { Younger } \\
\text { than } 10 \\
\text { years } \\
(10-)\end{array}$ & $\begin{array}{l}p \text {-value } \\
\text { Z-score } \\
\text { M/W } \\
\text { HE/OE } \\
10+/ 10-\end{array}$ \\
\hline $\begin{array}{l}\text { 1. Completely } \\
\text { agree }\end{array}$ & 3 & 3 & 0 & 1 & 2 & 2 & 1 & \\
\hline 2. Agree & 181 & 143 & 38 & 43 & 138 & 98 & 83 & \\
\hline Share in $\%(1+2)$ & 24.86 & 27.04 & 19.00 & 20.47 & 26.67 & 25.64 & 24.00 & \\
\hline $\begin{array}{l}\text { 3. I don't have a } \\
\text { position }\end{array}$ & $\begin{array}{c}386 \\
52.16\end{array}$ & 268 & 118 & 116 & 270 & 199 & 187 & \\
\hline 4. Disagree & 156 & 116 & 40 & 50 & 106 & 86 & 70 & $\begin{array}{l}0.6599 \\
0.3524 \\
0.4965 \\
\end{array}$ \\
\hline $\begin{array}{l}\text { 5. Completely } \\
\text { disagree }\end{array}$ & 14 & 10 & 4 & 5 & 9 & 5 & 9 & $\begin{array}{l}0.8966 \\
0.5823 \\
0.1971\end{array}$ \\
\hline Together: $4+5$ & 22.97 & 23.33 & 20.00 & 25.58 & 21.90 & 23.33 & 22.57 & $\begin{array}{l}0.5961 \\
0.2801 \\
0.8026\end{array}$ \\
\hline Total: & 740 & 540 & 200 & 215 & 525 & 390 & 350 & \\
\hline $\begin{array}{l}\text { chi-square/ } \\
\text { p-value }\end{array}$ & & $\begin{array}{l}7.0705 \\
0.1319\end{array}$ & & $\begin{array}{l}3.6582 \\
0.4542\end{array}$ & & $\begin{array}{l}2.5787 \\
0.6306\end{array}$ & & \\
\hline
\end{tabular}

Source: own calculation.

The research results confirmed that there is no statistically significant difference in the overall responses of microenterprises disaggregated according to the gender and education of the entrepreneur, and the age of the company. The p-values are as follows: gender - 0,1319, 
education $-0,4542$, age $-0,6306$. These facts allow us to reject our working alternative hypothesis $\mathrm{H} 3$ in relation to all monitored factors.

Our assumption that a maximum of $30 \%$ of entrepreneurs agree with the opinion, that credit conditions are transparent was also confirmed, when only $24.86 \%$ of entrepreneurs in the segment microenterprises consider the conditions under which banks provide loans to SMEs are transparent.

Basic finding which arises from this part of the research is that microenterprises do not consider lending criteria to be transparent and also declare some degree of disinterest, respectively, ignorance of the issue, as up to $52.16 \%$ of entrepreneurs were unable to take a position on this matter. According to some studies, it is clear that a large number of entrepreneurs uses bank loans (eg. Kalusová (2014) stating that $61 \%$ of entrepreneurs in Slovakia uses bank loans, while the interest in getting bank financing is much higher), and at the same time these entrepreneurs cannot assess the transparency of credit conditions.

The results of our study support the conclusions by Bain \& Company, Inc., and the Institute of International Finance (2013), European Association of Craft, Small and mediumsized Enterprises (2007), and OECD (2006).

Table 4 presents the results of the research in the area of evaluation of usefulness of knowledge of credit conditions.

Table 4. The results in the field of improving access to bank loans

\begin{tabular}{|c|c|c|c|c|c|c|c|c|}
\hline $\begin{array}{l}\text { Better } \\
\text { understanding of } \\
\text { credit terms and } \\
\text { conditions } \\
\text { would help the } \\
\text { entrepreneurs to } \\
\text { improve an } \\
\text { access to credit } \\
\text { and increase the } \\
\text { interest in the } \\
\text { loans }\end{array}$ & Total & Men & Women & $\begin{array}{l}\text { Secondary } \\
\text { education }\end{array}$ & $\begin{array}{l}\text { Other } \\
\text { types of } \\
\text { education }\end{array}$ & $\begin{array}{l}\text { Older } \\
\text { than } 10 \\
\text { years } \\
(10+)\end{array}$ & $\begin{array}{c}\text { Younger } \\
\text { than } 10 \\
\text { years } \\
(10-)\end{array}$ & $\begin{array}{c}\text { p-value } \\
\text { Z-score } \\
\mathrm{M} / \mathrm{W} \\
\mathrm{HE} / \mathrm{OE} \\
10+/ 10-\end{array}$ \\
\hline $\begin{array}{l}\text { 1. Completely } \\
\text { agree }\end{array}$ & 75 & 53 & 22 & 18 & 57 & 39 & 36 & $\begin{array}{l}0.6384 \\
0.3077 \\
0.8966 \\
\end{array}$ \\
\hline 2. Agree & 430 & 309 & 121 & 132 & 298 & 212 & 218 & $\begin{array}{l}0.4237 \\
0.2460 \\
\mathbf{0 . 0 2 9 3} \\
\end{array}$ \\
\hline $\begin{array}{l}\text { Share in \% } \\
(1+2)\end{array}$ & 68.24 & 67.03 & 71.50 & 69.77 & 67.62 & 64.36 & 72.57 & $\begin{array}{l}0.2460 \\
0.5687 \\
\mathbf{0 . 0 1 6 4} \\
\end{array}$ \\
\hline $\begin{array}{l}\text { 3. I don't have a } \\
\text { position }\end{array}$ & 176 & 130 & 46 & 48 & 128 & 101 & 75 & \\
\hline 4. Disagree & 52 & 42 & 10 & 13 & 39 & 34 & 18 & \\
\hline $\begin{array}{l}\text { 5. Completely } \\
\text { disagree }\end{array}$ & 7 & 6 & 1 & 4 & 3 & 4 & 3 & \\
\hline Total: & 740 & 540 & 200 & 215 & 525 & 390 & 350 & \\
\hline $\begin{array}{l}\text { chi-square/ } \\
\text { p-value }\end{array}$ & & $\begin{array}{l}2.7217 \\
0.6054\end{array}$ & & $\begin{array}{l}4.8579 \\
0.3022\end{array}$ & & $\begin{array}{l}6.9688 \\
0.1375\end{array}$ & & \\
\hline
\end{tabular}

Source: own calculation. 
The research results confirmed that there is no statistically significant difference in the overall responses of microenterprises disaggregated according to the gender and education of the entrepreneur, and the age of the company. The p-values are as follows: gender - 0,6054, education $-0,3022$, age $-0,1375$. These facts allow us to reject our working alternative hypothesis $\mathrm{H} 4$ in relation to all monitored factors.

We have also confirmed our assumption that the opinion that better knowledge of credit criteria allows the entrepreneurs to have an easier access to credit and to better price conditions will be presented by a minimum of $60 \%$ of entrepreneurs in the segment of microenterprises. According to our findings, more than $60 \%$ of entrepreneurs agreed with this statement. Partial differences were found in attitudes of microenterprises, according to their age $(p$-value $=0.0164)$. In our research older companies have demonstrated a greater dose of pessimism in that area because only $64.36 \%$ of them agreed with this statement. This trend, namely that older firms more negatively evaluate commercial banks' approach to credit financing, several times appeared in our research, while the focus of our research does not adequately allow us to explain this phenomenon, and that is why it would be necessary to conduct further research in this area.

Kalusová (2014) described the effect of crisis on financial options of microenterprises by stating that the tightening of credit standards by the banks was in many ways reflected in specific credit terms and conditions - bank margins, as well as riskier loans, significantly increased above the average level, banks demand higher collateral for the loan and the terms of loans were tightened. The main reasons for the rejection of the bank loans to microenterprises are the insufficient volume of assets to guarantee the loan, short credit history of enterprises as well as low credit rating.

In connection with the implementation of the rules of Basel II banking regulation many SMEs are confronted with internal rating procedures or credit scoring systems by their banks. The banks require more and better quality information from their clients and will assess them in a new way. Both up-coming developments are already causing increasing uncertainty amongst SMEs. In order to reduce this uncertainty and to allow SMEs to understand the principles of the new risk assessment, it is important to demand transparent rating procedures - rating procedures may not be a "Black Box" for SMEs: the bank should communicate the relevant criteria affecting the rating of SMEs, the bank should inform SMEs about its assessment in order to allow SMEs to improve (European Association..., 2007).

These "black box effects" are a limitation of credit scoring models that has to be taken into account insofar as it may put at risk the transparency of the relationship between SMEs and their banks. Banks are more likely to explain to SMEs the rationale for not granting access to credit if they can base their decision on a rating, while they may have difficulties in justifying the outcome of a scoring model. Moreover, scoring tools are based on statistics, i.e. the "classification error" may cause a SME willing to have access to financing to be eliminated due to a classification error. This error is generally around $20 \%$, one SME out of five. Therefore, credit scoring techniques should rather be regarded as an auxiliary tool in the process of credit granting, rather than the cornerstone of a credit selection process (supplementary tool in the process of granting credit, rather than a cornerstone of selective loan process) (OECD, 2006).

It is necessary that the owners of small and medium-sized enterprises were able to provide transparent information to the banks. Owner-managers must become more aware about the need for transparency towards investor transparent and open exchange of information about the situation and the perspectives of their companies. In order to fulfill the new needs for transparency, SMEs will have to use new information instruments (business plans, financial reporting, etc.) and new management instruments (risk-management, financial management, etc.) (European Association..., 2007). According to Bain \& Company, Inc. and 
the Institute of International Finance (2013) Higher-quality, lower-cost information is a key to unlocking more sources of finance for SMEs.

Despite of the development of more sophisticated decision-making and financial modeling approaches by the banks, with the support of increased market intelligence and developments in relationship banking that may help to overcome these informational and reputational effects, theoretical arguments suggest that there is, nevertheless, a number of categories of SME owners that could be affected by informational issues or reputational effects.

These involve the following categories: younger SMEs and younger entrepreneurs with limited trading records and security, female and ethnic minority entrepreneurs (from reputational effects), fast growing firms especially in manufacturing and technology-related sectors, out of the 'norm' situations where SMEs owners have unusual business propositions, such as high growth proposals from SME owners in rural environments (Deakins et al., 2008).

Proper credit information can remove the problem with the asymmetric information and that can foster the SME loans in the emerging markets. It's often claimed that SMEs in emerging countries with the lower level of economic freedom and higher corruption index have the lower possibility of getting formal finance from the banks. Higher level of corruption discourages the bankers to lend to such informational opaque firms like SMEs. High level of corruption increases the financing gap for SMEs at least in the less economically developed countries (Dong and Men, 2014).

Deakins, Whittam, and Wyper (2010) state that SMEs were turned down to access funds from the banks due to poor presentation of the loan proposals by the SMEs owners, although the businesses were financially solvent and it looked like they would repay the loans. According to these authors, information gap between SMEs and banks can be reduced through good banking relationships and when the owner of the SME provides all necessary information to the bank managers. It increases the trust of the bank managers and that can help to access funds from the bank.

\section{Conclusion}

The aim of this paper was to define and quantify significant risk factors of microenterprises' credit financing in the current dynamic economic environment and to compare the significant position of these undertakings in relation to commercial banks by gender, education of the entrepreneur and the company's age. The paper is based on the survey of the quality of the business environment carried out in 2015 in Czech Republic on a sample of 1141 small and medium sized enterprises, 740 of which were reported as microenterprises.

The results of our research have confirmed that the importance of credit risk has grown during the crisis, which was confirmed by more than $60 \%$ of the total number of microenterprises that were contacted in the context of our research. In this area no significant differences within defined groups of microenterprises were identified.

An important finding resulting from our research is that microenterprises do not thoroughly know credit conditions of commercial banks. This trend was found in the whole spectrum of analyzed microenterprises.

A significant finding is that microenterprises do not consider lending criteria to be transparent and also declare some degree of disinterest, respectively, ignorance of this issue, because more than $50 \%$ of entrepreneurs were unable to take a position on this matter.

Our research confirmed the impact of the age of the company in the perception of the growing important of the credit risk during the crisis, and the level education of the 
entrepreneur in relation to the familiarity with the conditions under which the banks provide loans. All other monitored factors do not have any statistically significant impact on the monitored risk factors in the loan process. Our results show that the main problems of the micro enterprises are an absolute unfamiliarity with the credit conditions of the commercial banks across the entire spectrum of the researched groups, and their persuasion of the lending criteria to be non-transparent.

Based on the presented data we can conclude that the knowledge and understanding of credit conditions, transparent approach by the banks and SMEs in the context of minimizing information asymmetry creates conditions for better and more effective access to bank loans.

Like other scientific researches our research has certain boundaries and limits, as it was performed on a limited sample of respondents through predefined methodological tools. The limited geographical focus only on the Czech Republic is also significant because country's specific macro environment can also affect the possibility to get the loan by the SMEs (Drakos and Giannakopolous, 2011). A wider geographical focus of the further researches may bring more fundamental results. Nevertheless, it can be assumed that it could be an interesting inspiration for the field of scientific knowledge and for the development of the practical procedures in the field of financial risk management of small businesses.

The research results point to the need for deeper analysis of certain matters in the field of microenterprises' credit risk management. Our future research will be aimed on the differences in the approach of older and younger microenterprises to the selected attributes of credit risk management.

\section{References}

Armstrong, A., Davis, E. P., Liadze, I., Rienzo, C. (2013), An assessment of bank lending to UK SMEs in the wake of the crisis, National Institute Economic Review, 225(1), pp. 3961.

Ardic, O. P., Mylenko, N., Saltana, V. (2012), Access to finance by Small and Medium enterprises: a cross-country analysis with a new data set, Pacific Economic Review, Vol. 17(4), pp. 491-513.

Bain \& Company, Inc. and The Institute of International Finance (2013), Restoring Financing and Growth to Europe's SMEs. Available at: http://www.bain.com/Images/REPORT_Restoring_financing_and_growth_to_Europe's SMEs.pdf

Bartoš, P., Ključnikov, A., Popesko, B., Macháček, J. (2015), Are men more innovative and aggressive in business? Case study from the Czech Republic, International Journal of Entrepreneurial Knowledge, Issue 2, Vol. 3, pp. 29-39.

Beck, T., Lu, L., Yang, R. (2015), Finance and Growth for Microenterprises: Evidence from Rural China, World Development, Vol. 67, pp. 38-56.

Beck, T. (2013), Bank financing for SMEs - lessons from the literature, National institute economic review, Vol. 67(1), pp. 23-38.

Belás, J., Demjan, V., Habánik, J., Hudáková, M., Sipko, J. (2015a), The business environment of Small and medium-sized companies in selected regions of the Czech Republic and Slovakia, E+M. Ekonomie a Management, Vol. 18, Issue 1, pp. 95-110.

Belás, J., Bilan, Y., Demjan, V., Sipko, J. (2015b), Entrepreneurship in SME segment: Case study from the Czech Republic and Slovakia, Amfiteatru Economic, 17 (38), pp. 308326.

Belás, J., Bartoš, P., Ključnikov, A., Doležal, J. (2015c), Risk perception diff erences between micro-, small and medium enterprises, Journal of International Studies, Vol. 8, No 3, 2015, pp. 20-30. DOI: 10.14254/2071-8330.2015/8-3/2 
Belás, J., Macháček, J., Bartoš, P., Hlawiczka, R., Hudáková, M. (2014), Business risks and the level of entrepreneurial optimism of SME in the Czech and Slovak Republic, Journal of competitiveness, Vol. 6, Issue 2, pp. 30-41.

Berrone, P., Gertel, H., Giuliodori, R., Bernard, L., Meiners, E. (2014), Determinants of Performance in Microenterprises: Preliminary Evidence from Argentina, Journal of Small Business Management, 52(3), pp. 477-500.

Brauers, W. K. M., \& Zavadskas, E. K. (2011), Multimoora Optimization Used to Decide on a Bank Loan to Buy Property, Technological and Economic Development of Economy, 17(1), pp. 174-188.

Bruhn, M. (2013), A tale of two species: revisiting the effect of registration reform on informal business owners in Mexico, Journal of Development Economics, 103, pp. 27583.

Buganová, K., Hudáková M., Dvorský, J. (2014), The Assessment of the Impact of the Security Risk on the Amall and Medium-sized Enterprises in the Slovak Republic, 2014 $2^{\text {nd }}$ International Conference on Management Innovation and Business Inovation (ICMIBI 2014), Bangkok, Dec 08-09, 2014. Book Series: Lecture Notes in Management Science, Vol. 44, pp. 116-121.

Carson, M. (2013), Adapting in tough times: The growing resilience of UK SMEs, Zurich: Economist Intelligence Unit. Available at: http://insider.zurich.co.uk/wpcontent/uploads/2013/06/Adapting-in-Tough-Times-The-Growing-Resilience-of-UKSMEs.pdf

Carter, S., Shaw, E., Lam, W. and Wilson, F. (2007), Gender, Entrepreneurship, and Bank Lending: The Criteria and Processes Used by Bank Loan Officers in Assessing Applications, Entrepreneurship Theory and Practice, Vol. 31(3), pp. 427-444.

Deakins, D., Whittam, G., Wyper, J. (2010), SMEs access to bank finance in Scotland: an analysis of bank manager decision making, Venture Capital, Vol. 13(3), pp. 193-209.

Deakins, D., North, D., Baldock, R., Whittam, G. (2008), SMEs' Access to Finance: Is there still a debt finance gap? Belfast: Institute for Small Business \& Entrepreneurship.

De Mel, S., McKenzie, D., Woodruff, C. (2008), Returns to capital in microenterprises: evidence from a field experiment, Quarterly Journal of Economics, 123, pp. 1329-72.

Doležal, J., Šnajdr, J., Belás, J. Vincúrová, Z. (2015), Model of the loan process in the context of unrealized income and loss prevention, Journal of International Studies, Vol. 8, No. 1, pp. 91-106. DOI: 10.14254/2071-8330.2015/8-1/8

Dong, Y., Men, C. (2014), SME financing in emerging markets: firm characteristics, banking structure and institutions, Emerging Markets Finance and Trade, Vol. 50(1), pp. 120149.

Drakos, K., Giannakopolous, N. (2011), On the determinants of credit rationing: firm level evidence from transition countries, Journal of International Money and Finance, Vol. 30, pp. 1773-1790.

Economic \& Social Research Council (2010), The effect of the credit crisis on UK SME finance. Available at: http://www.esrc.ac.uk/_images/Evidence\%20briefing\%20$\% 20$ finance $\%$ 20for\% 20 SMEs tcm8-13957.pdf

European Association of Craft, SMEs (2007), Crafts, Trades and SMEs need better access to finance. Available at: www.ueapme.com/.../041027_SME-finance_final.d

Fetisovová, E., Hucová, E., Nagy, L., Vlachynský, K. (2012), Aktuálne problémy financií malých a stredných podnikov, Bratislava: Ekonom.

Global Markets Institute (2014), Giving credit where it is due How closing the credit gap for women-owned SMEs can drive global growth, New York: Goldman Sachs International. 
Hernández-Cánovas, G., Koëter-Kant, J. (2013), SME financing in Europe: Cross-country determinants of bank loan maturity, International Small Business Journal, 29(5), pp. 489-507.

Holton, S., Lawless, M., McCann, F. (2013), SME financing conditions in Europe: credit crunch or fundamentals? National Institute Economic Review, Vol. 225 (1), pp. 52-67.

International Finance Corporation (2013), Closing the Credit Gap for Formal and Informal Micro, Small, and Medium Enterprises, World Bank Group: Washington, USA. Available http://www.ifc.org/wps/wcm/connect/4d6e6400416896c09494b79e78015671/Closing+t he + Credit+Gap+Report-FinalLatest.pdf?MOD=AJPERES

Irwin, D., Scott, J. M. (2010), Barriers faced by SMEs in raising bank finance, International Journal of Entrepreneurial Behavior and Research, Vol. 16(9), pp. 245-259.

Kozubíková, L., Belás, J., Bilan, Y., Bartoš, P. (2015a), Personal characteristics of entrepreneurs in the context of perception and management of business risk in the SME segment, Economics \& Sociology, Vol. 8, No. 1, pp. 41-54.

Kozubikova, L, Belás, J., Kljucnikov, A., Virglerova, Z. (2015b), Differences in Approach to Selected Constructs of Entrepreneurial Orientation in SME Segment Regarding the Selected Socio-Demographic Factors, Transformations in Business \& Economics, Vol. 14, No. 3C (36C), pp. 42-59.

Larson, D. W., Shaw, T. K. (2001), Issues of microenterprise and agricultural growth: do opportunities exist through forward and backward linkages? Journal of Developmental Entrepreneurship, 6(3), pp. 203-220.

Kalusová, L. (2014), Problémy získavania bankových úverov slovenskými MSP, MMK 2014: Sborník př́spěvků z mezinárodní vědecké konference, ročník V., 15.-19. prosince 2014, Hradec Králové, Česká republika, pp. 1463-1469.

McCarthy, S., Oliver, B., Verreynne, M. L. (2015), Bank financing and credit rationing of Australian SMEs, Australian Journal of Management, Vol. 28 (1), pp. 1-28.

Mentel, G., Brożyna J. (2015), Compatibility of market risk measures, Journal of International Studies, Vol. 8, No 2, 2015, pp. 52-62. DOI: 10.14254/2071-8330.2015/8$2 / 5$

Mostenska, T.L., Bilan, Y.V., Mostenska, T.G. (2015), Risk management as a factor ensuring enterprises' economic security, Actual Problems of Economics, 170 (8), pp. 193-203

Munoz, J. M., Welsh, D. H. B., Chan, S. H., Raven, P. V. (2015), Microenterprises in Malaysia: a preliminary study of the factors for management success, Int Entrep Manag J, 11, pp. 673-694.

North, D., Baldock, R., Ekanem, I. (2010), Is there a debt finance gap relating to Scottish SMEs? A demand side perspective, Venture Capital, Vol. 12(3), pp 173-192.

OECD (2014), Financing SMEs and Entrepreneurs, An OECD Scoreboard, OECD Publishing.

OECD (2006), The SME Financing Gap. Theory and Evidence, Vol. I., OECD Publications: Paris.

Rauch, A., Rijsdijk, S. A. (2013), The Effects of General and Specific Human Capital on long-Term Growth and Failure of Newly Founded Businesses, Entrepreneurship Theory and Practice, Vol. 37(4), pp. 923-941.

Rupeika-Apoga, R. (2014), Financing in SMEs: Case of the Baltic States, Procedia-Social and Behavioural Sciences, Vol. 150, pp. 116-125.

Shuying, Z., Mei, Z. (2014), Theory of SMEs financial risk prevention and control, International Conference on Education, Management and Computing Technology (ICEMCT 2014), pp. 514-517. Available at: www.atlantispress.com/php/downloadpaper.php 
Skapa, S. (2013), Commodities as a Tool of Risk Diversification, Equilibrium. Quarterly Journal of Economics and Economic Policy, Volume 8, Issue 2, pp. 65-76.

Sobeková Majková, M., Solík, J., Sipko, J. (2014), The Analysis of Chosen Business Obstacles and Problems with the Financing of Young Entrepreneurs in Slovakia, Economics \& Sociology, 7(3), pp. 90-103.

Sobeková Majková, M. (2011), Analýza bariér a faktorov financovania malých a stredných podnikov v SR, Journal of Economics, Vol. 59 (10), pp. 1028-1032.

Yildirim, H. S., Akci, Y., Eksi, I. H. (2013), The Effect of Firm Characteristics in Accessing Credit for SMEs, Journal of Financial Services marketing, Vol. 18(1), pp. 40-52.

Závadský, J., Hitka, M., Potkány, M. (2015), Changes of employee motivation of slovak enterprises due to global economic crisis, E+M Economics and Management, Vol. 18, No. 1/2015, pp. 57-66.

Welsh, D. H. B., Munoz, J. M., Deng, S., Raven, P. V. (2013), Microenterprise performance and microenterprise zones (MEZOs) in China, Management Decision, Vol. 51(1), pp. 25-40.

http://www.socscistatistics.com/tests.

http://www.socscistatistics.com/tests/ztest/Default2.aspx. 